\title{
The effectiveness of the cooperative learning model with mind mapping type in German writing skill (schreibfertigkeit)
}

\author{
Ambo Dalle \\ Faculty of Languages and Literature \\ Universitas Negeri Makassar \\ Makassar, Indonesia
}

\begin{abstract}
This research was a quasi-experiment in the form of Nonequivalent Control Group design that aims to find out the effectiveness of the cooperative learning model with mind mapping type in German writing skill (Schreibfertigkeit). The populations of this research were all students on class XI IPA MAN 1 Makassar consisting of 45 students. The sampling techniques that were performed in this research was purposive sampling. The inferential statistical analysis was used in this study to test the research hypothesis by using t-test. This research found that the cooperative learning model with mind mapping type is effective in improving writing skills of the students on class XI IPA MAN 1 Makassar.
\end{abstract}

Keywords—cooperative learning; mind mapping; writing skill, effectiveness

\section{INTRODUCTION}

German Lesson is one of the subjects in formal education in Indonesia, Foreign language learning is less desirable by students because it has a high difficulty level compared to English. Therefore, learning German requires an interesting method of learning. In the German language learning, four language skills should be taught, namely reading skills (Leseverstehen), listening skills (Hörverstehen), writing skills (Schreibfertigkeit), and speaking skills (Sprechfertigkeit). Also, it must be supported by two aspects of capabilities, namely: grammar (Strukturen) and vocabulary (Wortsatz).

Good writing in the German language is not as easy as writing in the Indonesian language. The students must master the structure and vocabulary of the German language. Also, the mastery of themes and ideas that will be written is also required. One of learning models that can help to improve students' speaking skills is a cooperative learning model. In cooperative learning model, students are given the opportunity to interact actively in group learning. Cooperative learning is a series of learning activities performed by students in certain groups to achieve the learning objectives that have been formulated [1].

The cooperative learning model is not as simply as learning in groups. Some basic elements distinguish cooperative learning with the division of the group that carried out carelessly [2]. The implementation of cooperative learning with the correct procedure would allow teachers to manage classes effectively". Some strategies of cooperative learning can be applied to conversational skills. One of them is mind mapping, which is a visual form of note-taking that recommends a general idea of a topic and its various information, permit students to grasp, produce new ideas and construct the link. Mind mapping promotes students to commence with an essential idea and enlarge noticeable to more in-depth sub-topics through the use of colours, images and words [3].

Mind mapping is an advantageous learning means to facilitate students brainstorming every topic for creative thinking. Mind maps are principally accommodating in the process of writing and endow students with a normal technique of thinking and building thoughts based on the theme [4]. Mind maps present teachers with insight into their students' thought process concerning an exact issue. Teachers might be able to recognise the student's prior knowledge and their understanding level on the assignment or the material being taught by asking students to create mind maps. Mind mapping facilitates students to demonstrate their comprehension of a concept. This is a considerably effective way of evaluating students' understanding.

In the cooperative learning model with mind mapping type, students are expected to apply the concept or keyword on every point of the material that has been given. These keywords are used to facilitate explanation of each point on the given theme. Thus, the learning process becomes more focused, so that students write down their ideas easily to avoid saturated learning atmosphere in the classroom.

Furthermore, mind mapping is an effective tool for learners to make links between the topics and themes. Mind mapping makes their learning outcomes persist longer [5]. Mind mapping is very effective for visual learners. The type of mind mapping is intended so that the students can be more experienced to explore the prior knowledge that has been owned. It is also expected to acquire new knowledge based on learning experiences [6]. 


\section{METHOD}

This research was a quasi-experiment research design in the form of Nonequivalent Control Group design. In this study, the researcher involved two groups, namely experimental class, and control class. In the experimental class, the researcher used cooperative learning model with mind mapping type. In the control class, the researcher did not use any learning model of the German language of writing skills in the first grade of natural sciences students at MAN 1 Makassar. (Table 1)

TABLE I. THE RESEARCH METHOD

\begin{tabular}{|l|l|l|}
\hline Group & \multicolumn{1}{|c|}{ Type } & \multicolumn{1}{|c|}{ Treatment } \\
\hline 1 & Experiment & $\begin{array}{l}\text { Cooperative learning and mind } \\
\text { mapping }\end{array}$ \\
\hline 2 & Control & Conventional method \\
\hline
\end{tabular}

This study consisted of two variables namely independent and dependent variable. The independent variable in this study is the implementation of cooperative learning model of mind mapping (X), and the dependent variable is writing skill (Y).

The populations in this study were all students of XI IPA at MAN 1 Makassar consisting of 3 classes. The samples were selected using purposive sampling. Class XI IPA 2 was chosen as the experimental class in which the number of students was 15 person, and class XI IPA 1 class was the control class in which the number of students was 15 person.

Criteria for the measurement of the variables that have been used were the criteria for assessment of writing skills based on elements of German writing skills used by teachers at Man 1 Makassar. The assessment criteria are as follows:

TABLE II. THE ASSESSMENT CRITERIA OF WRITING SKILLS

\begin{tabular}{|l|l|l|}
\hline No. & \multicolumn{1}{|c|}{ The Assessed Components } & \multicolumn{1}{|c|}{$\begin{array}{c}\text { The Maximum } \\
\text { Score }\end{array}$} \\
\hline 1 & Contents of ideas & 50 \\
\hline 2 & Grammar & 30 \\
\hline 3 & Vocabulary & 20 \\
\hline & Total & 100 \\
\hline
\end{tabular}

The data were analyzed using inferential statistical analysis to test the hypothesis by using t-test. However, before testing the hypothesis, tests of normality were performed using a table- $Z$ score and the chi-square and homogeneity test using the $\mathrm{F}$ test (Fisher). Before determining the data normality test, homogeneity, and hypothesis testing, researchers must first determine the score of mean, standard deviation, and variance.

\section{RESULT AND DISCUSSION}

\section{A. Result}

The results of the data analysis obtained from the test results of students in writing a simple essay about Essen und Trinken, both in the experimental class and in the control class. Each class was given pre-test with the same questions to find out the essay writing skills. In the control class, researchers used a conventional method. Then the experimental class was given treatment namely the use of cooperative learning model with the type of mind mapping. After four meetings, the two classes were given post-test with same questions. The obtained data can be presented in the following data analysis.

The experimental class (IPA 2) is treated by using cooperative learning model with mind mapping type and control class (IPA 1) using the conventional method in four times meeting; both classes were given post-test to see the level of the writing skills of students in each class after learning. Based on the scores obtained from the posttest in the experimental class, the mean from 15 students was 80.67 . The peak score was 85 , and the lowest was 72 . From the calculations, the interval is 2.6 rounded to 3 , and the amount of class is 5 .

Data frequency and percentage of post-test values in the experimental class shows that from the 15 students, two students $(13 \%)$ attained the score of the interval class with a range of score is $72-74$. No student $(0 \%)$ received the score in the interval class with a range of scores between 75-77. Two students $(13 \%)$ attained the score of the interval class with a range of scores between 78 and 80 . Eight students (54\%) achieved the score of the interval class with a range of scores between $81-83$. There were three students $(20 \%)$ who attained the score of the interval class with a range of scores between 84 and 86 . Based on the score obtained from the post-test in the control class, the mean of 15 students was 72.27 , the highest score was 80, and the lowest score is 46 . Based on calculations, the range is 6.8 which is rounded to 7 , and the number of classes is 5. (Fig.1)

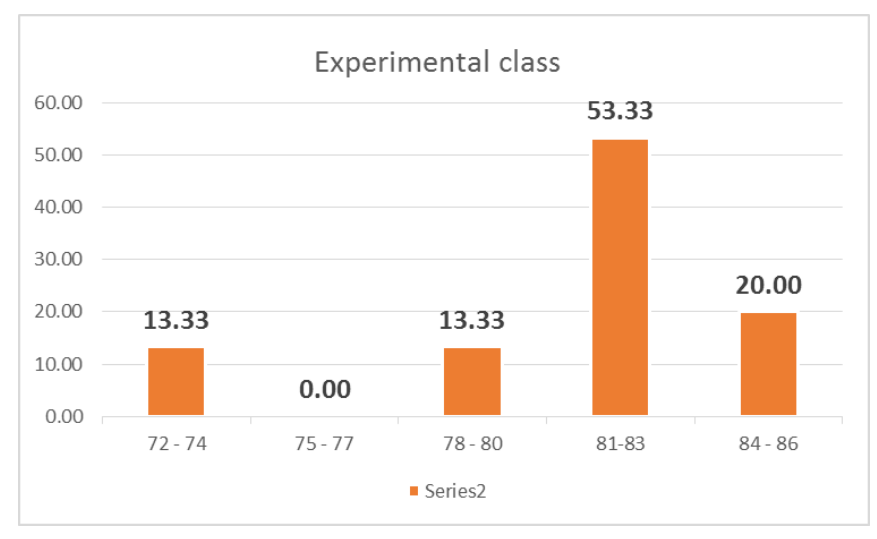

Fig. 1. The distribution value of experimental class

Data frequency and percentage of post-test scores in the control class, there is one student $(7 \%)$ who obtain the score in interval class with the score range is $46-52$. No student $(0 \%)$ get the score in interval class with the score range is 53-59, One student $(7 \%)$ attained scores in interval class with the score range is $60-66$. Five students $(33 \%)$ attained the score in the interval class with the score range is 67-73. Eight students (53\%) attained the score in the interval class with the score range is 74-80. (Fig.2) 


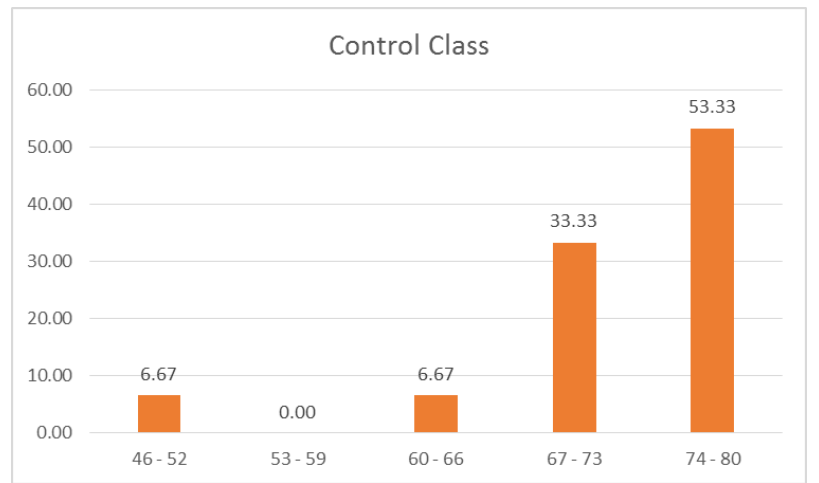

Fig. 2. The distribution value of experimental class

The results of data analysis using t-test formula indicate that the value of $t$ is 4.24 . The value of tcount is then compared with the value of ttable with df $=n_{1}+n_{2}-2=$ $15+15-2=28$ at the level of alpha 0.05 , then it is found $t \mathrm{t}=$ 2,048. Based on the criteria of hypothesis testing that is rejected if $\mathrm{HO}$ is rejected $\mathrm{t}_{\mathrm{h}_{\mathrm{s}}}>\mathrm{t}_{\mathrm{t}_{\mathrm{s}}}$ and $\mathrm{H} 1$ is rejected if

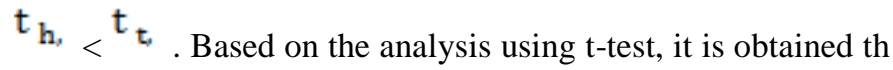
$=4.24$ and $\mathrm{tt}=2.048$, then $\mathrm{th}=4.24>\mathrm{tt}=2.048$.

Therefore, H0 stating that the cooperative learning model with mind mapping type is ineffective in writing skills of students of class XI IPA MAN 1 Makassar is rejected. The consequence of the rejection of $\mathrm{H} 0$ is that $\mathrm{H} 1$ which states that cooperative learning model with mind mapping types is effective in writing skills class XI IPA MAN 1 Makassar is accepted. The rejection of $\mathrm{H} 0$ and the acceptance of $\mathrm{H} 1$ show that the cooperative learning model with Mind Mapping type is effective in learning German language writing skills in class XI IPA MAN 1 Makassar.

\section{B. Discussion}

In this research, the learning process was conducted during four meetings. In the learning process, both classes (experimental and control class) were taught using a different technique. In the experimental class, the students were taught using cooperative learning model with Mind Mapping type in German writing skill. Whereas, in the control class, the students were taught using conventional model.

The results of post-test show that the mean score for the experimental class is 80.67 and the means score of control class is 72.27 in writing skill in which the achievement score for the experimental class is 1.210 and control class is 1.084 . The normality test on the post-test data in experimental and control class shows that both classes have chi-square count that is lower than chi-square table, $X_{\text {hitung }}<X_{\text {tabel }}$, in which the result of pre-test in experimental class is $-69.96<$ 9.49 and the result of post-test in the control class are $-87.36<$ 9.49. Therefore, the distribution of pretest data is stated normal.

Based on the results of post-test, the use of cooperative learning model with mind mapping type has a positive effect on the improvement of writing skill. It is proven by the students' post-test score in which the minimum score in the experimental class is 72 , the maximum score is 85 , and the mean is 80.67 . Whereas in control class, the minimum score that is found is 46 , the maximum score is 80 , and the mean is 72. 27. The above analysis is continued with t-test to find the final result of this research for each by using the same formula. The result is ${ }^{t}$ count of the experimental class is 4.24 meanwhile $t_{\text {table }}$ is 2.048. Therefore, $\mathrm{t}_{\text {count }} \geq \mathrm{t}_{\text {table }}(4.24 \geq 2.048)$.

Therefore, $\mathrm{H} 0$ that states that cooperative learning model with Mind Mapping type is not effective in the learning of German writing skill of the students on class XI IPA MAN 1 Makassar is rejected. The consequence of the rejection of H0 is that $\mathrm{H} 1$ which states that the cooperative learning model with mind mapping type is not effective in writing skills of the students on class XI IPA MAN 1 Makassar is accepted. Hence, it can be concluded that the research on the effectiveness of cooperative learning model with mind mapping type in the writing skills of the students on class XI IPA MAN 1 Makassar is declared successful.

This research found that the cooperative learning model with mind mapping type is effective in writing skills of the students on class XI IPA MAN 1 Makassar. Mind mapping is a creative way for students individually to produce ideas, record the lesson, or plan a new study [7]. By instructing the students to create a mind map, they will find an easiness to identify clearly and creatively what they have learned and what they plan.

\section{CONCLUSION}

Based on the analysis of data, which has been described above, it can be concluded that the use of cooperative learning model with mind mapping type is effective in writing skills of the students on class XI IPA MAN 1 Makassar. It is proven by the result of t-test analysis of students' score in posttest after performing a t-test for each class in which the result of data analysis is th $=4.24>\mathrm{tt}=2.048$ on the significance level 0.05 . It means that there is a significant improvement after using the cooperative learning model with Mind Mapping type in which $\mathrm{Th}$ is higher than Tt. It shows that the use of cooperative learning model with mind mapping type is effective in improving writing skills of the students on class XI IPA MAN 1 Makassar.

\section{REFERENCES}

[1] J. Vella, Taking Learning to Task: Creative Strategies for Teaching Adults. The Jossey-Bass Higher and Adult Education Series. ERIC, 2000 .

[2] A. Lie, "Jigsaw: A Cooperative Learning Method for the Reading Class,” Waco, Texas Phi Delta Kappa Soc., 1994.

[3] R. C. Clark and R. E. Mayer, E-learning and the science of instruction: Proven guidelines for consumers and designers of multimedia learning. John Wiley \& Sons, 2016.

[4] Y. Liu, G. Zhao, G. Ma, and Y. Bo, "The effect of mind mapping on teaching and learning: a meta-analysis," Stand. J. Educ. Essay, vol. 2, no. 1, pp. 17-31, 2014. 
[5] R. R. Schmeck, Learning strategies and learning styles. Springer Science \& Business Media, 2013.

[6] C. M. Reigeluth, Instructional-design theories and models: A new paradigm of instructional theory, vol. 2. Routledge, 2013.
[7] M. Silberman, Active Learning: 101 Strategies To Teach Any Subject. ERIC, 1996. 